\title{
SMALL RUMINANT INDUSTRY IN SRI LANKA - PART III
}

\section{Policy guidelines recommended by GOSL for goat and sheep breeding}

Policy guidelines for goat breeding have been formulated and published as a document in 1994, by the National Breeding Committee of the Ministry of Agriculture, Lands and Forestry for the benefit of all those engaged in livestock breeding, including goats (National breeding policy guidelines for livestock in Sri Lanka, 1994). This document covers the breeding policy guidelines for cattle, buffaloes, goats, sheep and pigs both in the state farms and in the private sector.

The objective of this was to streamline and bring about some degree of uniformity in livestock breeding activities carried out by the farms and institutions of the state sector departments and corporations as well as the private sector farms spread throughout the country. In recommending these guidelines, primary consideration has been given to agro-climatic zones in the country as well as to the socio-economic conditions and different management systems practiced by farmers. The breeding policy guidelines recommended for each agro-ecological zone has been designed to assist the farmer to get a genetically superior animal that could be managed by him, with the existing environment and inputs available to him in the locality.

The breeding policy recommended for both large and small ruminants in general is crossbreeding for the production of superior generations possessing higher production potential. It has been emphasized that feeding and management levels of the progeny should be improved simultaneously with the genetic upgrading, if one were to achieve the desired increase in efficiency and productivity. The recommended breeding strategy for goats is given in Table 23. Goat breeds maintained in the state livestock farms in 1994 and the recommended policy is given in Table 24. However, it is observed that these recommendations are followed more in the breech, perhaps due to the lack of awareness or disregard to the recommendations and the lack of a proper monitoring program.

\section{Sheep Breeding}

The recommended program for breeding sheep is to upgrade the indigenous stock to the recommended imported breed (Indian breeds like Bannur or Red Madras) to produce a better meat type animal in the Dry zone, Coconut triangle, Jaffna, Low-country wet zone and Hill-country. The emphasis on development is mainly in the Coconut triangle and Dry zone. Sheep breeding in the state farms in 1994 and policy recommendations are given in Table 23.

\section{Potential and prospects of small ruminant development in Sri Lanka}

Small Ruminant production is an important and viable sub sector of animal production in Asia, and is true for Sri Lanka as well in respect of goats. However, there has been no significant growth or development of this sector over the past several years. The goat population in the country has remained more or less stagnant at about 0.5 million since 1991, while the sheep population has recorded a sharp negative growth in the past 20 years. Goat rearing is often a subsidiary source of income and sometimes the lively-hood of a large number of small and marginal farmers, living mainly in the dry and the dry intermediate zones. This situation has not improved very much during the last two decades.

Majority of the rural and the urban poor classes in Sri Lanka suffer from acute protein deficiency at present. National estimates for malnutrition in Sri Lankan pre-school children (1988-89) reflected alarming levels of nutritional problems, namely $36.4 \%$ of the population showed stunting (based on height for age), $18.4 \%$ wasting (based on weight for height) and $5.2 \%$ exhibited both deficiencies concurrently. Examination of the relationship between family income and child nutrition in 1991 and 1992 suggest that children in large families are at greater risk of having lower nutritional status (Ratnayake et al., 1991, 1992).

Dr. D.H.A.Subasinghe, Faculty of Veterinary Medicine and Animal Sciences, University of Peradeniya 
Table 23. Breeding Strategy for Goats in Sri Lanka

\begin{tabular}{|l|l|l|l|}
\hline Agro-climatic zone & Breeding emphasis & Production system & \multicolumn{1}{|c|}{ Recommended breeds } \\
\hline Hill country & Dairy & $\begin{array}{l}\text { Intensive and } \\
\text { Extensive }\end{array}$ & Saanen \\
\hline Mid country & Dairy & $\begin{array}{l}\text { Intensive } \\
\text { Extensive }\end{array}$ & $\begin{array}{l}\text { Beetal and Saanen } \\
\text { Beetal }\end{array}$ \\
\hline $\begin{array}{l}\text { Low country } \\
\text { Wet zone }\end{array}$ & $\begin{array}{l}\text { Dual purpose } \\
\text { (milk/meat) }\end{array}$ & $\begin{array}{l}\text { Intensive } \\
\text { Extensive }\end{array}$ & $\begin{array}{l}\text { Jamnapari, Beetal, Saana } \\
\text { Sri Lanka Boer }\end{array}$ \\
\hline $\begin{array}{l}\text { Low country } \\
\text { Dry zone }\end{array}$ & Meat & $\begin{array}{l}\text { Intensive } \\
\text { Extensive }\end{array}$ & $\begin{array}{l}\text { Jamnapari, Beetal, SLBoer } \\
\text { Kottukachchiya, Jamnapari x KK }\end{array}$ \\
\hline Coconut triangle & $\begin{array}{l}\text { Dual purpose } \\
\text { (milk/meat) }\end{array}$ & Intensive & $\begin{array}{l}\text { Jamnapari, Beetal, Saanen } \\
\text { Jamnapari, and Beetal. }\end{array}$ \\
\hline Jaffna peninsula & $\begin{array}{l}\text { Dual purpose } \\
\text { (milk/meat) }\end{array}$ & $\begin{array}{l}\text { Intensive } \\
\text { Extensive }\end{array}$ & $\begin{array}{l}\text { Jamnapare,Saanen,Beetal } \\
\text { Jamnapari, Beetal }\end{array}$ \\
\hline
\end{tabular}

Source: Scharge et al , 1997, National Breeding Policy Guidelines for Livestock in. S.L. (1994)

Sri Lanka Boer $=(50 \%$ Boer $) ; \mathrm{KK}=$ Kottu Kachchiya breed

Majority of the rural and the urban poor classes in Sri Lanka suffer from acute protein deficiency at present. National estimates for malnutrition in Sri Lankan pre-school children (1988-89) reflected alarming levels of nutritional problems, namely $36.4 \%$ of the population showed stunting (based on height for age), $18.4 \%$ wasting (based on weight for height) and $5.2 \%$ exhibited both deficiencies concurrently. Examination of the relationship between family income and child nutrition in 1991 and 1992 suggest that children in large families are at greater risk of having lower nutritional status (Ratnayake et al., 1991, 1992).

It has also been revealed that high incidence of stunting and wasting is found in families where the father's occupation is farming or fishing. The interpretation could be that the family incomes are low and more or less seasonal. Children of such families are at greater risk of becoming malnourished. It is estimated that 6.1 million persons representing 39.5\% of the population in Sri Lanka are in poverty (Livestock Sector Policy Review, 1992). Approximately 5.1 million rural people are in nutritional poverty. Although the nutritional level in the urban sector has improved, the rural sector has not progressed. This could perhaps be attributed to the reduction in subsidies, inflation and the decline in income level of the rural poor resulting in the manifestation of nutritional deficiencies among the poverty groups.

Since the Government's poverty alleviation programs in the form of food stamps, mid-day meals to schools, "Janasaviya" and "Samurdhi" have not been sustainable, emphasis was shifted from consumption oriented welfare assistance to production oriented programs. The more recent poverty alleviation programs therefore aim to increase the earning capacity of the poor through dual strategy of rural work coupled with the provision of credit and support services. This strategy aims to encourage self-employment and increase enterprise development. Development of the livestock sector offers a feasible production oriented approach to rural development, with its associated positive impact on employment, income generation, improved nutrition, reduction of the rural-urban migration and an expansion in the rural based agro-industries. The small ruminant subsector is certainly a viable avenue of employment and rural based economic enterprise. It requires a relatively low investment cost, and is an ideal employment opportunity, for rural youth and the females in the household. Considering the current status of the small ruminant industry, the low level of productivity and its contribution to the food supply and economy of the country, it is important to examine the potential and prospects and exploit the available resources, for its development.

Benefits that the country could accrue through a fresh boost to this rural industry would certainly be tremendous. Meat and milk from goats can meet a good proportion of the protein deficiency among children and other vulnerable groups, if the rural farmers are encouraged and supported to rear goats. It would at least provide their own household requirement of milk which will benefit firstly the most vulnerable and needy members of the family (children, invalids, pregnant females and nursing mothers), while the surplus could be sold in the village or nearest town center to bring some additional income to the family. Conversion of milk to yogurt or cheese will result in a significant value addition and marketability to the product, while the sale of surplus animals in the herd will provide an added income, in times of cash needs of the family. 
Table 24. Breeds of goats \& sheep maintained on state farms and Policy recommendations (1994)

\begin{tabular}{|c|c|c|c|c|}
\hline Breeds available & $\begin{array}{l}\text { Breeding policy } \\
\text { Recommendations }\end{array}$ & Farm & Zone & Organization \\
\hline \multicolumn{5}{|c|}{ Goats } \\
\hline Saanen & To be maintained pure & New Zealand & Hill country & NLDB \\
\hline Beetal & To be maintained pure & Nikaweratiya & $\begin{array}{l}\text { Coconut } \\
\text { triangle }\end{array}$ & NLDB \\
\hline Boer & $\begin{array}{l}\text { To be maintained pure } \\
\text { Production of SL Boer } \\
\text { ( } 50 \% \text { Boer) to be continued } \\
\text { large scale } \\
\text { Production of } 75 \% \text { Boer } \\
\text { Crosses to be continued } \\
\text { in a small scale }\end{array}$ & $\begin{array}{l}\text { Kottukachchiya } \\
\text { Sorabora } \\
\text { Kottukachchiya } \\
\text { Kottukachchiya }\end{array}$ & $\begin{array}{l}\text { Dry zone } \\
\text { System C } \\
\text { Dry zone } \\
\text { Dry zone }\end{array}$ & $\begin{array}{l}\text { NLDB } \\
\text { MASL } \\
\text { NLDB } \\
\text { NLDB }\end{array}$ \\
\hline Boer crosses & $\begin{array}{l}\text { Production of SL Boer } \\
\text { (50\% Boer) to be continued }\end{array}$ & $\begin{array}{l}\text { Niraviya } \\
\text { Kirindi oya }\end{array}$ & $\begin{array}{l}\text { System H } \\
\text { Kirindi oya }\end{array}$ & $\begin{array}{l}\text { MASL } \\
\text { Kirindioya } \\
\text { Project } \\
\end{array}$ \\
\hline Kottukachchiya & To be maintained pure & $\begin{array}{l}\text { Weerawila } \\
\text { Ridiyagama }\end{array}$ & $\begin{array}{l}\text { Dry zone } \\
\text { Dry zone }\end{array}$ & $\begin{array}{l}\text { NLDB } \\
\text { NLDB }\end{array}$ \\
\hline Jamnapari crosses & To be upgraded to Jamnapari & $\begin{array}{l}\text { Kottukachchiya } \\
\text { Weerawila }\end{array}$ & $\begin{array}{l}\text { Dry zone } \\
\text { Dry zone }\end{array}$ & $\begin{array}{l}\text { NLDB } \\
\text { NLDB }\end{array}$ \\
\hline Crossbreds & To be upgraded to SL Boer & Polontalawa & Dry zone & NLDB \\
\hline German Fawn & $\begin{array}{l}\text { To be maintained pure } \\
+ \text { production of SL Fawn } \\
\text { ( } 75 \% \text { G.Fawn to be } \\
\text { continued) }\end{array}$ & Helamada & $\begin{array}{l}\text { Coconut } \\
\text { triangle }\end{array}$ & NLDB \\
\hline \multicolumn{5}{|c|}{ Sheep } \\
\hline Red Madras & To be maintained pure & Parasangas wewa & Dry zone & NLDB \\
\hline Bannur & To be maintained pure & Parasangas wewa & Dry zone & NLDB \\
\hline Bikaneri & To be maintained pure & Parasangas wewa & Dry zone & NLDB \\
\hline
\end{tabular}

Source: National Breeding Policy Guidelines for livestock in Sri Lanka (1994).

Note: Mahaweli Goat Farms aim to support the Sri Lanka Boer program by functioning as multiplier farms.

NLDB - National Livestock Development Board

MASL - Mahaweli Authority of Sri Lanka

Goat rearing can be made popular among the rural farmers, because the investment on resources is relatively low. Feed resources are generally available in one's own garden or in the neighborhood and the animals can be managed by surplus labour in the family such as women and children after school activities. The major investment on the enterprise would only be on modest housing requirements and the animals. Rural farmers who have financial constraints will have to be assisted by the GOSL through suitable financial institutions such as commercial or development banks. Such institutions can provide the farmers with concessionary loans for the purchase of animals, housing and technical assistance for initial establishment.

Since more than $70 \%$ of the population in Sri Lanka is rural based, and are engaged in agricultural pursuits, majority of them could be encouraged to take up to goat production as a viable form of self-employment. More over a vast resource of underutilized fodder base quite suitable for goats is available in the dry zone districts of Sri Lanka. However, the present problem of low productivity of the indigenous stock could be overcome by the implementation of a suitable upgrading program coupled with good nutrition and management. The government's objective of increasing rural employment and income generation could be achieved in this manner, to some extent. Rural farmers could also be assisted financially and technically through the present Government's Gama Neguma Program.

However, the constraints faced by the industry at the present time (mentioned earlier in this document) have to be overcome to achieve any significant progress. Inputs and services to the farmers need to be considerably strengthened and expanded, to make their activity more effective and meaningful. It would also be necessary to place renewed emphasis on institutional development, research and technology transfer by the 
government at the central, regional and village levels, to achieve the laid down objectives. Adequate and sustained financial provision from lending agencies and the state sector will be essential, to support such a program. The Ministry of Livestock Development, Ministry of Economic Development, DAPH, NLDB, MASL and the Provincial Ministries in-charge of the subject of livestock development will have to work together on a sustainable program with set targets achievable within a given time frame. Given the necessary incentives and support of the government, private sector can also be encouraged to participate actively in such development programs. It must also be emphasized that any development program should have an efficient and effective project monitoring and evaluation mechanisms built into the program, to ensure proper implementation and achievement of the desired benefits to the target population.

\section{Development strategies and the government's role in future programs}

For the implementation of an effective small ruminant development program, accepted policies concerning the sub-sector should be followed. The identified priority areas should also be actively supported by the GOSL. At the outset it is important to set out the production objectives in order to maximize productivity from goats and sheep, e.g. meat, milk and hides. To improve the efficiency and economic viability of the enterprise, these objectives should be related to optimum productivity, market demand and sales outlets etc.

\section{Meat production}

In meat/mutton production, both quality and quantity of the carcass meat are important considerations. Birth weight and growth rate of animals are related to production efficiency of meat. Total number of animals available for slaughter will reflect on weight gain and weights of kids weaned/year/female.

\section{Milk production}

In milk goats, lactation yield, lactation length and persistence of milk and the number of lactations per female are important. Additionally the amount of butter fat and solids not fat (SNF) will determine the quality of milk. Therefore, production potential and nutrition of the animals as well as the managerial skills of farmers should be improved to achieve the desired production parameters.

\section{Reproduction}

Improvement of the reproductive efficiency of the stock will also contribute to increase in the number of births and production output in milk, meat etc. Steps should be taken to obtain acceptable weight gain, early maturity, increased breeding efficiency and reduction in kidding interval.

\section{Improvement in feeding managemen}

While breeding and selection programs are long term, improved nutrition and feeding management can bring about rapid and remarkable benefits. Effective use of the available fresh feed resources, agro-industrial by-products and non-conventional feeds in the feeding of small ruminants (goats and sheep) would certainly improve the performance of the animals and output per unit area of land. Poor performance of the local animals is a reflection of the underutilization of the feed resources observed mostly in the Asian region (Devendra, 1986). Deficiency in dietary proteins is observed as a limiting factor. Hence provision of supplementary proteins through concentrate feeds such as coconut poonac, soybean meal, rice polish etc. would meet the protein requirements, but the cost of such products is usually high. Therefore, protein rich legumes may be given to fill this need. Leaves of tree legumes such as Gliricidia, Leucaena, Sesbania and Erythrina are rich sources of supplementary energy and protein that can be fed at low cost. These plants could be easily established along the perimeter fence or as hedgerows. Fodder leaves from these trees could be harvested 3-4times/year, and can withstand drought conditions. Bush legumes such as Stylosanthus may be fed with grasses, to improve the quality of feed. In addition to the these leguminous fodders, leaves of commonly available plants like jak fruit (Artocarpus heterophyllus), neem (Azadirachta indica), hibiscus (Hibiscus rosa sinensis), siras (Albizzia lebbeck), cassava (Manihot esculenta racntz) and banana (Musa spp.) can be used as a rich forage base in goat production.

\section{Conservation of forages}

In many parts of the country including the Dry zone there is a lush growth of grass and other forages during the rainy seasons. However, most of it goes waste, as the farmers are not used to conserve them for future use. If this forage is harvested at the proper time, they could be conserved as hay or silage and used when required. Conservation technology has to reach the farmer effectively through awareness programs and farmer training.

\section{Utilization of crop residues}

It has been reported that about 5 million metric tons (MT) of crop residues are produced annually in Sri Lanka, and of this rice straw amounts to 3.2 million MT (Rajaguru, 1987). Rice straw is an abundant feed resource in most parts of Sri Lanka, especially in the Dry zone. Straw if properly dried and stored away, it can be used even up to two years, to feed both large and small ruminants during times of feed 
shortage. The intake of straw and its digestibility can be increased by treatment with urea at appropriate concentration (1-4\%) depending on the method of treatment before feeding or by the use of urea-molasses-multi nutrient-blocks (UMMB) fed to ruminants as a supplement, in combination with straw as a basal diet. The use of rice straw as a basal diet supplemented with UMMB for small ruminant feeding has been successful and cost effective in many South Asian countries (Devendra, 1986). Sugarcane tops may also be used in a similar manner for small ruminant feeding. This can be successfully implemented in districts like Monaragala, Ampara and Kantale where sugarcane production is undertaken on a large scale.

\section{Effective utilization of land under plantation crops, for small ruminant production}

Sri Lanka has a large extent of land under coconut (444,950 ha) and rubber (162,524 ha) where the natural vegetation/grass is not utilized (Dept. of Census and Statistics, 1997). Most of the coconut plantations are in the Coconut Triangle, and is ideal for small ruminant production. Assuming that the carrying capacity of the land is 4 goats or sheep per ha and only $50 \%$ of the land is used for this activity, it would be possible to support about 0.9 million sheep or goats from the natural vegetation available under coconut alone. However, if improved fodder grasses like Pannicum, Brachiaria or Napier varieties and creeping legumes are cultivated under coconut and inter cropped with tree legumes such as leucaena (e.g.Leucaena leucocephala) or gliricidia (e.g.Gliricidia maculata), the fodder base can be considerably increased and the carrying capacity of animals doubled or trebled, depending on the inputs on the enterprise.

If sheep or goats are raised for mutton, the off-take from such a project will be tremendous. Based on the current annual extraction rate of $18 \%$ goats from the national herd for slaughter, $0.9 \mathrm{~m}$ goats/sheep will provide 162,000 animals/year. The total annual mutton production from this would be about 2268 MT (Based on the assumption that each slaughtered animal would yield about $14 \mathrm{~kg}$ meat).This is about 2.5 times the mutton produced locally at present and 12.5 times the amount of mutton (182 MT) imported to the country in 2001. Similar projections could be made for sheep/goat production under rubber plantations as well which could produce 816 MT of mutton annually. Therefore, these two plantation sub-sectors alone can produce approximately 3000 MT of mutton annually for the consumer market as a new source of supply. This shows clearly the tremendous potential in the country that has not been tapped to produce the much needed protein requirements of the nation and at the same time save the foreign exchange used annually for meat imports.

Development priorities in the small ruminant subsector can be broadly classified into several categories namely (a) breeding and breed improvement, (b) research, (c) extension and technology transfer, (d) veterinary services and (e) marketing.

\section{(a) Breeding and breed improvement}

Production parameters of the indigenous goats are usually poor in relation to crossbreds like Sri Lanka Boer or purebreds like Jamnapari, Beetal and Saanen or their crosses. Since the indigenous animals and the nondescript goats form the bulk of the national herd, crossbreeding and upgrading of the local females to selected males of superior breeds will bring about a quick improvement in the genetic quality and productivity of the progeny. Rapid improvement in the genetic base of the foundation stock could be achieved in this manner.

The breeding policy of the country has to be formulated after having considered the type of farming systems practiced in the different agroecological zones and the type of animal found suitable to upgrade the local stock in each system or region. If the objective is meat production, Boer or Sri Lanka Boer would be the (male) animal of choice to upgrade the indigenous goats in the Dry zone. Past experience indicate that the crossbred progeny of such a program has performed well in the Dry zone. On the other hand, when the primary objective is milk production, superior male of an appropriate breed type has to be selected for the upgrading program. In doing so environmental conditions in the specific region should be taken into consideration; e.g. breeds like Jamnapari or Beetal can be the breeds of choice to upgrade the indigenous stock in the Dry zone and Dry Intermediate zones. Jamnapari males may be used even for a dual-purpose (meat and milk) objective. It is recognized that temperate breeds like Saanen and German Fawn have a high milk production potential. Selected male animals of these breeds may be used to upgrade the local low producing stock in the plantation sector in the Hill and Mid country where climatic conditions are more favorable to the temperate breeds and their progeny. The Ministry of Agriculture, Lands and Forestry published a document on the National Breeding Policy Guidelines for Livestock in Sri Lanka in 1994. However it is noted that the guidelines and recommendations are not closely followed at the present time. This is perhaps due to the lack of monitoring programs to ensure the success of implementation. Newer technologies such as the use of artificial insemination (AI) and 
embryo transfer (ET) could be used to implement an accelerated breeding program.

\section{(b) Nucleus breeding farms}

To meet the national requirement of superior breeding stock for an upgrading program, large number of good quality animals possessing high genetic potential should be available for issue to farmers. Such a large number could be produced only in large breeding stations equipped for it. Therefore, it would be necessary to establish several such goat-breeding stations in the different agro-ecological zones maintaining animals of high genetic merit and simultaneously suited to the particular environment. Such breeding stations should maintain a minimum herd of 300 breeding females and 20 - 25 stud males of each breed type. The genetic potential of the animals have to be upgraded through a process of continuous selection, so that the progeny will possess the desired merit for milk or meat depending on the particular objective. Nucleus farms established in different agro-ecological zones of the country (especially in the popular goat producing areas) should breed genetically superior stock well adapted to the respective zone and issue them as foundation stock required for the multiplication farms.

Genetic upgrading, breed improvement and their stabilization have to be designed, directed and monitored by skilled geneticists. The geneticists of the DOA and DAPH conducted this type of research and development in the Government livestock farms until the end of 1991. However, on a Government directive the livestock farms of the DAPH were vested with the NLDB (Statutory Board) in 1992. It is noted that low priority has been given to planned breeding and research by the NLDB. Perhaps, this may be due to the lack of research scientists in the NLDB or low priority given to small ruminant production. Further, the commercial orientation of the NLDB may have influenced such action. Nevertheless it must be pointed that the small ruminant research and development programs and steps taken for the preservation of the gene pool by the DAPH should be continued by the successive agencies like the NLDB, as it is a vital national need.

The production of good quality animals in large numbers to meet the public demand for breeding stock has to be done by the government Ministry/agency entrusted with the subject of livestock development. With the skilled human resources available in the DAPH and the physical and human resources of the NLDB, this can be done, provided the necessary directions and the active support of the Ministry of Livestock Development are made available. Perhaps the new
Ministry of Economic Development could assist in this task.

Breeding programs of the NLDB should be reviewed and rescheduled where necessary, in consultation with the DAPH geneticists and in line with the National Breeding Policy Guidelines, to produce the best quality animals (particularly males) adapted to the different agro-ecological zones. Suitable action has to be taken to conserve breeds like "Kottukachchiya breed" that has been locally evolved by our own research scientists, as they have certain desirable characters like disease resistance and adaptability to dry zone conditions. The females of this breed have also been used to develop the Sri Lanka Boer goats by crossing to pure Boer goats imported from South Africa. In addition to the Kottukachchiya and the Sri Lanka Boer breeds, other tropical breeds like Beetal, Jamnapari and temperate breeds like Saanen and German Fawn that were imported in the recent past at great expense to the country should be conserved and upgraded in the state farms. Prospects and feasibility of importation of new breeding stock should be examined only after undertaking a full assessment of the available resources in the country. There is a goat-breeding program managed by the Animal Breeding Division of the DAPH at present. It would be prudent to coordinate such activities as well into a national program. The National Breeding Committee of the Ministry of Livestock Development can give the necessary guidelines and directions for such a program. The technical expertise of the University scientists particularly those of the Faculty of Veterinary Medicine \& Animal Science could also be used in such a national Endeavour.

Distribution of superior male genetic material for the upgrading of farmers' low producing stock would make a significant impact on the national heard in a short period of time. The National Breeding Committee of the Ministry should be revived and properly reconstituted, so that it could meet regularly to give the necessary directions and also monitor and evaluate the progress of the national programs from time to time. Policy guidelines should also be reviewed from time to time, to meet the emerging needs of the country and to keep abreast of the newer trends in small ruminant production.

\section{(c) Multiplication farms}

As the state sector farms producing superior breeding animals will not be able to cater to the demand for the field, the upgraded stock can be multiplied by encouraging and supporting the private sector farms and the plantation sector to develop "multiplication farms". They may be large or medium size establishments, depending on the 
resources of the farmer. Non-Governmental Organizations (NGOs) and the state and private sector plantations possessing the necessary resources and skills can be enlisted to undertake such activities, by providing the necessary incentives and training. Such farms should be provided with the required technical and financial assistance at the outset, by the government agencies involved in livestock development and rural development or commercial banks, to enable them to establish their enterprise successfully. They should preferably be established in different agroecological locations of the country, so that they will produce superior stock with high production potential and are also well adapted to the given environment. These farms will procure the appropriate foundation stock from the nucleus breeding farms of the NLDB or import them under Government approval, for multiplication in their own establishments. If good feeding, management and healthcare are provided, a significant output of breeding animals can be issued from such farms. The quality of the progeny issued from the "multiplication farms" should be regularly checked and monitored by the National Breeding Committee (NBC) and the relevant line agencies of the Livestock Ministry. This system has been successfully implemented by the DAPH with goat and pig breeding some years back (1980s) and should have no difficulty now, provided the goals and method of approach are set correctly.

\section{Research strategy}

Livestock research has an important place in supporting development policies and programs. Development relies strongly on political will and the national policy is the expression of government activity. This is influenced by research in several ways (a) by providing solutions to development problems, or (b) presenting new information to the government for allocation of funds for new projects. For a developing country like Sri Lanka the former aspect is more relevant.

Small ruminant research needs can vary with many factors such as the economic importance of goats, land use and management practices and traditional farming systems of the country or region. In countries of the south Asian region including Sri Lanka production from goats and their utilization is generally low. This is mainly due to slow growth, high kid mortality, poor production, inefficient marketing and shortage of capital (Copeland, 1994). In relation to research on large ruminants, the quantum of research conducted on small ruminants is little.

This again reflects on the priority given by successive governments for this sub-sector, for research and development. Although there have been a few research surveys done in the past, these studies have been limited to small population samples in selected areas. There is a need to undertake more broad based and well planned technical surveys to identify research priorities. At the same time, emphasis should be placed on applied research with technical and sociological inputs for the development of "technological packages" or "basket of technologies" relevant to the rural environment. Such packages that can be successfully adapted by the farmers would attract farmer attention as well as development support from the government and donor agencies. The program of priorities for research and development should include areas such as nutrition, breeding, disease control, management, product development and marketing. Another important area of research would be social and economic research relevant to ruminant production and more specifically small ruminants. However, they must be combined with technical research as a coordinated program.

\section{Nutrition}

Generally the quality, quantity and availability of feedstuff is inadequate to meet the nutritional requirements of the animals. Seasonal variations, cropping pattern and method of land utilization for forage production has had a negative effect on the quality and quantity of available fodder. Mature forages and crop residues are normally poor in quality and in addition, their supply and distribution systems are unstable. Research can be focused on a) the evaluation of different available forages, b) growth studies of different breeds and breed crosses on selected nutritional diets, c) influence of nutrition on fertility/reproduction in local, exotic and crossbred goats.

\section{Breeding}

Lack of sound breeding policies and continuous selection in breeding programs aimed at the improvement of meat and/or milk production results in low productivity of the animals. Poor knowledge and skill among goat farmers in the use of appropriate and best animals for breeding also contribute to poor performance. Therefore, technology developed in the research stations should be effectively transferred to the farming community. Farmer participation in such research can be still more effective and meaningful. Attention may be focused on the following areas as well: a) Selection within the existing population of native, crossbreds or imported breeds and b) evaluation of the potential of the milk breeds like Saanen, Jamnapari and Beetal and their crosses. Crossbreeding and upgrading programs conducted by the research scientists of the DAPH in the past have brought beneficial results to the country. Two outstanding examples are: a) the development of the "Kottukachchiya goat" a sturdy animal suitable 
for meat, adapted to dry zone environment possessing good disease resistant ability, b) the development of "Sri Lanka Boer goat" that is better suited for meat production, with improved birth weight, growth rate and enhanced meat production potential. Similar studies and programs aimed at the improvement of the milk production potential of the local and imported breeds have to be conducted in the future. Conservation of the newly developed breeds and other imported breeds should precede further selection and upgrading programs.

\section{Disease control}

There is a lack of awareness in most rural farmers on the prevalence and incidence of disease in goats and sheep. Kid mortality, pneumonia, parasitism, goat paralysis (cerebro-spinal nematodeasis), enterotoxaemia, foot and mouth disease, contagious pustular dermatitis (CPD) are some of the common ailments observed in goat farms. Except for the occasional investigations into parasitic problems, comprehensive epidemiological surveys have not been undertaken to identify the incidence of important disease entities. Economics of disease control in goats is another important area of research.

\section{Management}

Research has to be focused on the effect of housing and management on productivity. Investigation on low cost housing suited for the different agroecological zones, using commonly available material but incorporating essential features with regard to hygiene, safety and animal welfare would benefit the poor rural farmer most. Studies on the effect of nutrition on the age of maturity and age at first kidding in female goats can influence the reproductive efficiency of the goats.

\section{Product development}

There is hardly any published work on product development or research done with goat milk in Sri Lanka. Value addition and improvement of the keeping quality of goat milk will certainly enhance the supplementary income of the rural small ruminant farmers. Newer small and medium scale industries may emerge under such circumstances.

\section{Marketing and economics}

Market research is essential to develop inputs, to ensure that increased production is marketable. Development efforts are more successful if the products have a ready market. Analysis of cost/benefit at producer level will provide answers to farmers' problems and the benefits of the industry to the national economy.

\section{Research coordination required}

The primary orientation of research should be national development and it is the responsibility of every research scientist to contribute to this objective. For effective implementation of such a project, a program of research coordination has to be put in place. This becomes more important in conducting multidisciplinary research, because the researchers come from different disciplines and institutions. Formation of a research network would encourage researcher communication and also stimulate interactive research. Research coordination should be attempted at the regional level, national level as well as at the international level. The relevant ministries such as Agriculture and Livestock and Science and Technology and Higher Education should give the lead to muster the support of the National Research Institutes and the University system. Since research funding in Sri Lanka has always been low, establishment of such research networks could benefit both technologically and financially.

\section{REFERENCES}

Copeland, J.W. (1985). Goat production in the tropics Proceedings of a workshop held at the University of Queensland, Brisbane, Australia, 6-8 Feb,1984.(ACIAR Proceedings Series 7)

Department of Census and Statistics (1997). Agricultural Statistics of Sri Lanka

Devendra, C. (1986). Prospects of developing small ruminant production in humid tropical Asia. In: Small Ruminant Production Systems in South and South East Asia, C. Devendra (ed) p, $184-198$.

Livestock sector policy review, Sri Lanka (Technical Report funded by the Asian Development Bank) (1992), Brown, Copeland \& Co.

Ministry of Agriculture, Lands and Forestry (1994.) The National Breeding Policy guidelines for Livestock in Sri Lanka, October 1994

Rajaguru, A.S.B. (1987). Integration of crop and small ruminants in Sri Lanka. In: Small Ruminant Production Systems in South and Southeast Asia, C. Devendra (ed). Proceedings of a workshop held in Bogor, Indonesia, 6-10 Octobe, 1986, pp 190-202.

Ratnayake, R.M.K. (1991). Rural poverty alleviation in the Commonwealth. A case study- Sri Lanka. (Ministry of policy Planning and Implementation, Colombo)

Ratnayake, R.M.K. et al. (1992). Sri Lanka Country Paper to the International Conference on Nutrition. (Ministry of Policy Planning and Implementation, Colombo) 